\title{
Regional seismic activity in relation to tectonic structure in the PGG S.A. coal mines
}

\author{
Renata Patyńska ${ }^{1,{ }^{*}}$ Elżbieta Pilecka ${ }^{2}$, and Adam Mirek ${ }^{3}$ \\ ${ }^{1}$ PGG S.A., Katowice, Poland \\ ${ }^{2}$ Cracow University of Technology, Faculty of Civil Engineering, Krakow, Poland \\ ${ }^{3}$ State Mining Authority, Katowice, Poland
}

\begin{abstract}
The article presents seismological analysis in the mines of Polska Grupa Górnicza S.A. (PGG S.A.) in relation with the geological and tectonic structure of the exploited rock mass. There are grounds for seismic activity, to be associated with the structural features of the rock mass in which underground exploitation is carried out. The analysis included high-energy tremors (with energy $\mathrm{E}>10^{5} \mathrm{~J}$ ), which occurred in 2018. High energy tremors can cause mining damage on the surface. In 2018, three structural units out of five covering the Upper Silesian Coal Basin formed a rock formation coal mine of PGG S.A. The parameter analyzed was unit energy expenditure (JWE). It reflects the participation of two important pieces of information: total energy of tremors and mining of coal in a given period. The analysis shows that in 2018 JWE fell in total at PGG. However, it grew in the main trough, which translates into an increase in the risk of induced seismicity. Due to geological features, the area of exploitation covering the main trough, induces high-energy tremors that can cause effects on the surface. In other structural units, in 2018, JWE drops.
\end{abstract}

Keywords: coal mining, tectonic, rock mass, seismic activity

\section{Introduction}

Exploitation of coal deposits in the Upper Silesian Coal Basin (USCB) causes a disturbance of the balance of stress in the rock mass, both in the immediate and further vicinity of excavations $[1,2]$. The consequence of this process is, among others, the occurrence of rock mass tremors $[3,4,5]$. These phenomena in USCB are monitored by two independent registration systems: mine seismological networks and the regional system - the Upper Silesian Regional Seismological Network (GRSS) of the Central Mining Institute and local network in coal mines. The seismic hazard is determined by a number of natural and technical factors, the dominant of which are the strength parameters of coal and surrounding rocks [1, $2,3,4,6]$ and the magnitude of stresses in the vicinity of mining operations [7]. The stress state is usually shaped by the conducted operations in a given coal seam and in neighboring coal seams. There are many cases that subsidence caused by the mining exploitation correlates

\footnotetext{
*Corresponding author: rpatynska@gmail.com
} 
with the epicentre tremors [8]. The changes in lineaments locations in the zones of seismicity induced by mining are also observed $[9,10]$.

The research indicates that the analysis of tectonic structure, seismicity, development and dislocations of high stress areas and critical areas of elastic layer deformation enables both the definition of mining and geological factors determining location and energy of tremors [11]. It turns out that tremors with different focus mechanisms, and thus differing in spatial seismic impact, may have a different impact on the process of destruction of the rock mass, which results from the structural features of the region.

The article presents the characteristics of seismic activity in 2013-2018 in relation to the tectonic structure of the PGG S.A. mines. The level of seismic activity in the analyzed period fluctuated and depended on the intensity of exploitation and geological conditions in a given region.

\section{Outline of the tectonic structure of the Upper Silesian Coal Basin}

Upper Silesian Coal Basin is located on the Upper Silesian block. The tectonic structure of the USCB area is characterized by the presence of numerous folds, overlaps and faults, even visible on satellite images. Within the Upper Silesian block, several structures have been separated, which are characterized by a sub-arcuate arrangement and are separated by discontinuities. The northern part of the USCB lies within the Upper Silesian folding zone (five of fold-block tectonic zone). It includes such structural units as the Bytom trough, the Kazimierz trough and the main suddle and main trough) also Jejkowice trough and feld Jastrzębia. The Bytom trough is a structure with a complex structure. It is a series of shallow brachysynklin separated by dome-shaped elevations of the NW-SE course. The basin is asymmetrical. Its axis runs latitudinally from $\mathrm{W}$ to $\mathrm{E}$ near the north-east wing. This means that the northern wing is characterized by smaller fall angles (up to $17^{\circ}$ to the south) in relation to the opposite southern wing, where the fall angles reach up to $50^{\circ}$ locally. The complicated structure of the basin additionally disturbs the network of faults, mainly NW-SE and perpendicular to them, with various discharges and inclination angles.

The main suddle and main trough next to the Bytom trough is the most important element of the tectonics of the northern part of the USCB. It is built by a series of elevations cut with cross elevations, forming a series of "domes" stretching from west to east.

There are a number of fault structures in the area of the main saddle, the largest of which is the Kłodnica fault. It has a latitudinal course and is characterized by a variable amplitude of discharges and a variable angle of inclination of the fault plane. This structure dumps the layers to the south. The amplitude of the drop amounts from $360 \mathrm{~m}$ in its eastern part and then decreases in the western direction to about $20 \mathrm{~m}$. The Kłodnicki escarpment is accompanied by a series of smaller faults with discharges from a few to a dozen or so meters, staggered or fan-shaped and NE-SW faults with discharges from a dozen or so up to several dozen meters. The network of multi-directional faults of the lower orders, accompanying the Kłodnice fault, causes that the studied area was cut into a series of tectonic blocks of various sizes, differently displaced from each other, both vertically and horizontally. Therefore, this is an area that is very susceptible to any kind of deformation resulting from both past and present coal mining exploitation.

The central and south-eastern part of the USCB area is the Upper Silesian Pan (disjunctural tectonic zone). The largest area of this zone is occupied by the main trough. The main trough is the most extensive structure of the USCB. It is a very gentle and extensive trough with layers falling from 0 to $10^{\circ}$. Its main structural elements are numerous faults with various amplitude of discharges, often above $1 \mathrm{~km}$, and gentle deflections of layers in the form of domes, anticlines or troughs and synclines. The faults are usually normal drop-down and 
drop-and-shove are rarely just shifting. The length of the fault zones varies from a few meters to several dozen kilometers. Likewise, the orientation of the latitudes from the latitudinal to the meridian is different, while the latitudinal faults, which also have large discharges, are mainly collected in the central and southern part of the basin. Because they drop the rock mass to the south, they make the pan have a staircase in this part. On the other hand, meridian faults occur almost all over its area, and faults with the direction of NW-SE only along NE and $\mathrm{E}$ of its border.

The western part of the USCB is found in the Moravian-Silesian folding and folding band (folded tectonic zone) and is a zone of up to $20 \mathrm{~km}$ wide. The structural units are distinguished within it: the Jejkowice trough and the folding Jastrzębie. Folds have the character of overlap pointing to the east. In this region, the intensity of folds from the outside to the center of the basin is reduced. In the north-western part, the structure of the corrugated tectonics turns north-east and transform into structures west-east. This is related to the sliding movements in the ground along the northern split of the Bytom mine. In this zone, there are usually normal and slip-and-shift faults as well as several façades and transverse depressions. Three of the five structural units forming the USCB rock massif belong to the mines representing the PGGS.A. These are: main saddle and the main trough, the Jejkowice trough and the Jastrzębie folds (Table 1).

Table 1. List of branches of hard coal mines in 2018 based on membership in structural units forming the PGGS.A.

\begin{tabular}{|c|c|c|}
\hline No. & Coal mines & Structural units \\
\hline 1 & Bielszowice & \\
\hline 2 & Halemba & \\
\hline 3 & Murcki - Staszic & \\
\hline 4 & Mysłowice - Wesoła & \\
\hline 5 & Pokój & \\
\hline 6 & Ruda & \\
\hline 7 & Sośnica & \\
\hline 8 & Wieczorek & \\
\hline 9 & Wujek & \\
\hline 10 & Piast & \\
\hline 11 & Ziemowit & \\
\hline 12 & Chwałowice & \\
\hline 13 & Jankowice & \\
\hline 14 & Marcel & \\
\hline 15 & Rydułtowy & \\
\hline
\end{tabular}

\section{Characteristics of seismic activity in PGG S.A. coal mines in the period January-September 2018}

Occured in 6 hard coal mines, out of 8 constituting the PGG S.A. in 2018 it represented 8 mines consisting of 15 movements, of which 12 were classified as endangered by rock bursts up to I and or II degree. Analyses of dangerous events, including the number of registered tremors, indicate that the number of them is slowly but steadily growing. The reason for this phenomenon is in particular: increased exploitation depth and complex geological and mining conditions. In the seismic analysis of PGG S.A. mines the last 5 years include, for 
example, local seismic activity, as characteristic for a given mine, both for planned exploitation. The distribution of the number of high-energy tremors indicates the diversification of the rock mass by seismic activity in individual mining areas, including in particular its relationship with regional and structural tectonics.

The highest seismic activity and rock burst hazard in 2013-2018 were accompanied by mining operations: ROW, RUDA and Murcki-Staszic (Fig.1). In the Piast-Ziemowit Coal Mine there is periodic high seismic activity with no effects in underground excavations. Analysis of the location of the tremor sharks indicate their occurrence over the exploited seams. Essentially, high-energy tremors are strongly felt on the surface.

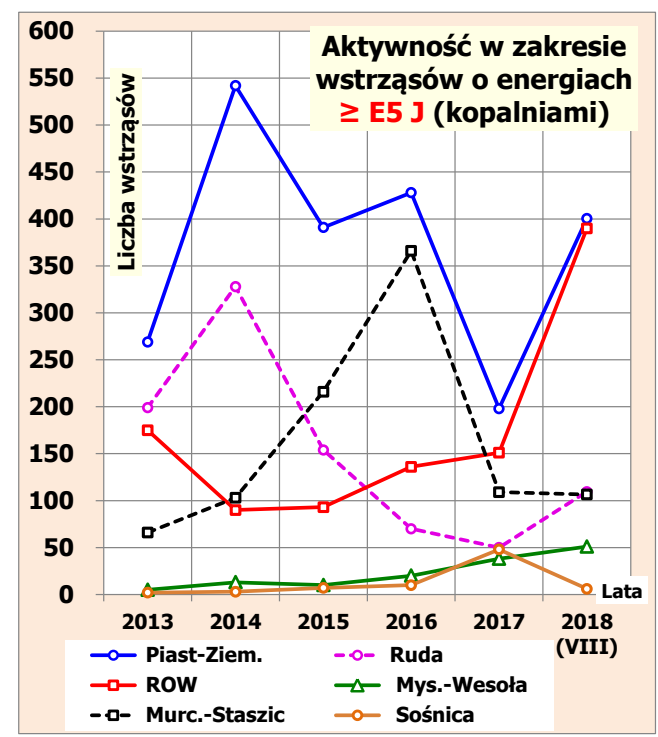

Fig. 1. Distribution of the number of seismic tremors in PGG S.A mines. from January 2003 to August 2018

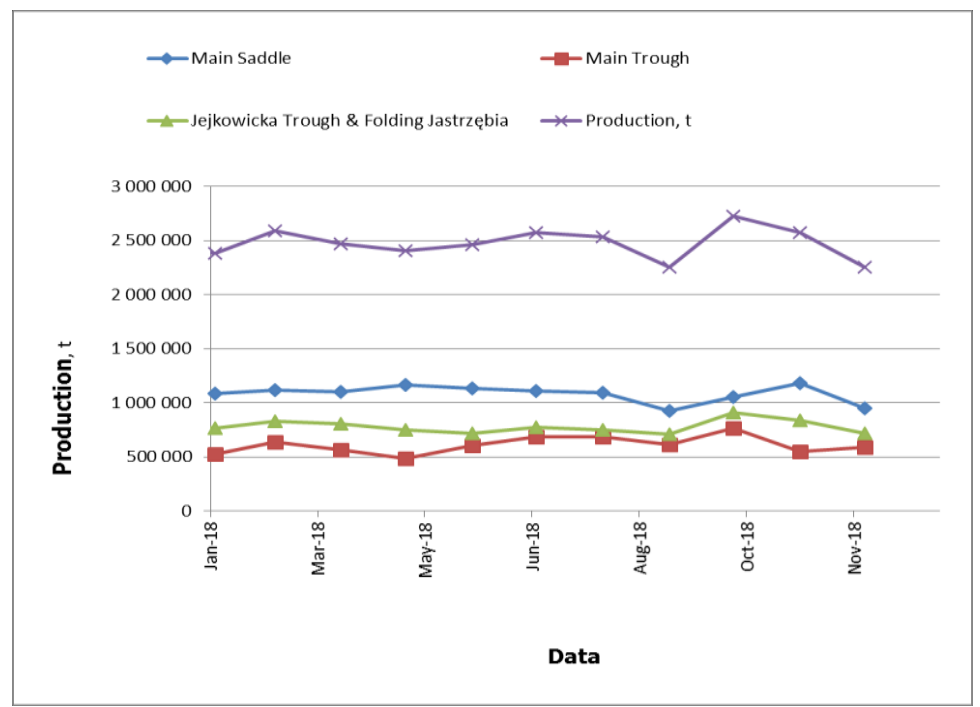

Fig. 2. Hard coal mining in the coal mines under the structural units PGG S.A. in 2018 


\section{The scale of seismic hazard of PGG S.A. mines depending on the tectonics of the rock mass}

The present research is based on a comprehensive measurement material from the coal mines of the Upper Silesian Coal Basin owned by PGGS.A. These are both data defining the nature and characteristics of the three structural units constituting the PGG S.A. rock mass. and current recording of seismic disturbances induced by mining works in mines. Analysis of seismic activity showed a decrease in production in all PGG S.A. structural units.

In 2018 in PGG S.A. mines 833 tremors with energy $\mathrm{E} \geq 10^{5} \mathrm{~J}$ were recorded, including 278 phenomena with energy of $10^{6} \mathrm{~J}$ and 24 tremors with energy $10^{7} \mathrm{~J}$ and three tremors with energy of $10^{8} \mathrm{~J}$. Table 2 shows all data of registered 1138 seismic tremors with energy $\mathrm{E} \geq 10^{5} \mathrm{~J}$ occurred in all PGG S.A. mines. Due to the location of particular mining areas of the hard coal mines included in the Group, they constitute the entirety of the regions, forming three of the five structural units distinguished in USCB (Table 2, Fig. 2, Fig. 3).

Table 2. Total of rock mass tremors energy E $\geq 10^{5} \mathrm{~J}$ registered in the year 2018 under structural units PGG S.A.

\begin{tabular}{|c|c|c|c|c|}
\hline \multirow{2}{*}{$\begin{array}{c}\text { Structural } \\
\text { Units }\end{array}$} & \multicolumn{2}{|c|}{ Total number of tremors } & \multicolumn{2}{c|}{$\begin{array}{r}\text { Total amount of energy of } \\
\text { tremors }\end{array}$} \\
\cline { 2 - 5 } & Total NPGG, J & Percentage rate & Sum EPGG, J & Percentage rate \\
\hline main suddle & 303 & 26.6 & $1.21 * 10^{9}$ & 40.1 \\
\hline main trough & 463 & $\mathbf{4 0 . 7}$ & $1.28 * 10^{9}$ & $\mathbf{4 2 . 4}$ \\
\hline $\begin{array}{c}\text { Jejkowicka } \\
\text { trough \& } \\
\text { Jastrzębie folds }\end{array}$ & 372 & 32.7 & $5.23 * 10^{8}$ & 17.3 \\
\hline PGG S.A. & 1138 & 100 & $3.02 * 10^{9}$ & 100 \\
\hline
\end{tabular}

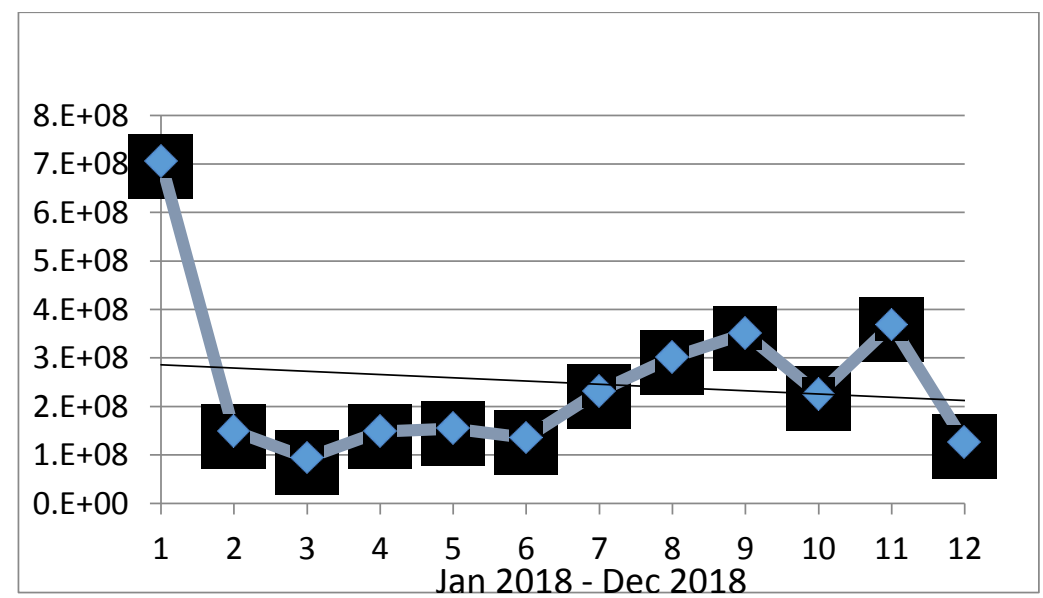

Fig. 3. Distribution of the sum of tremors energy from energy $\mathrm{E} \geq 10^{5} \mathrm{~J}$ in the coal mines of PGG in 2018 
Table 2, Figures 2 and 3 shows that the area in which there was a lot of highenergy tremors was the main trough. High energy tremors with energies of $10^{7}-10^{8}$ $\mathrm{J}$ occurred mainly during exploitation of Laziska layers, in which the seismically most active seams were the seams 207 and 209. The outbreaks of these tremors, according to expert analysis, are located high above the exploited seams, mainly near the occurring tectonic structures. The most seismically active area was the main saddle, surrounded by the Kłodnicki fault and faults accompanying in the main saddle. The seismic activity of this region was mainly related to the exploitation conducted in the Ruda and saddle layers (seams 418, 502, 510). In this region there are numerous faults with large discharges, which was important for the level of seismic activity. The maximum tremor concerns: main saddle - two tremors $6 * 10^{8}$ $\mathrm{J}$, the main trough - one tremor $1 * 10^{8} \mathrm{~J}$.

The area of the Jejkowice and Chwałowice basins was also characterized by a high level of seismic activity where the exploitation mainly deposits 703 and 713, caused the occurrence of the greatest number of tremors in this region. In this region, the presence of sandstone layers and the aggregation of the effects of multi-coal seam exploitation below these layers, which causes their collapse and generation of high energy tremors with energy of $10^{7}, 10^{8} \mathrm{~J}$, is of fundamental importance for the level of seismic activity. Table 3. Presents the monthly statement of unit energy expenditures of JWE $(\mathrm{J} / \mathrm{t})$ from energy $\mathrm{E} \geq 10^{5} \mathrm{~J}$ in PGG S.A. mines in 2018.

Table 3. Monthly statement of unit energy expenditures of JWE $(\mathrm{J} / \mathrm{t})$ in PGG S.A. mines in 2018

\begin{tabular}{|c|c|c|c|c|c|}
\hline Data & $\mathbf{J W E} \mathbf{E}_{M S}, \mathbf{J} / \mathbf{t}$ & $\mathbf{J W E}_{\mathbf{T J}}, \mathbf{J} / \mathbf{t}$ & $\mathbf{J W E}_{M T,}, \mathbf{J} / \mathbf{t}$ & $\begin{array}{c}\text { Production } \\
\mathbf{Q}, \mathbf{t}\end{array}$ & $\mathbf{J W E}_{\text {PGG, }} \mathbf{J} / \mathbf{t}$ \\
\hline Jan-18 & 482.72 & 114.39 & 161.86 & 2482104 & 287.41 \\
\hline Feb-18 & 26.90 & 37.57 & 172.74 & 2383122 & 88.28 \\
\hline Mar-18 & 20.24 & 59.35 & 34.39 & 2588184 & 41.67 \\
\hline Apr-18 & 39.03 & 47.03 & 118.27 & 2473664 & 65.21 \\
\hline May-18 & 63.28 & 24.66 & 128.28 & 2402671 & 69.58 \\
\hline Jun-18 & 17.93 & 51.61 & 68.38 & 2988376 & 49.51 \\
\hline Jul-18 & 9.90 & 77.34 & 234.94 & 2574901 & 94.43 \\
\hline Aug-18 & 5.16 & 78.77 & 343.97 & 2532552 & 124.18 \\
\hline Sep-18 & 214.12 & 39.06 & 201.22 & 2251866 & 162.68 \\
\hline Oct-18 & 48.44 & 56.21 & 161.68 & 2727752 & 89.80 \\
\hline Nov-18 & 155.66 & 37.30 & 275.28 & 2573623 & 149.12 \\
\hline Dec-18 & 62.83 & 37.41 & 68.06 & 2256956 & 60.73 \\
\hline
\end{tabular}

The following are the distributions of unit energy expenditures of JWE $(\mathrm{J} / \mathrm{t})$ from energy $\mathrm{E} \geq 10^{5} \mathrm{~J}$ in the months of January - December 2018 in PGG S.A.'s mines. (Fig. 4) and in individual geological and structural units of PGG (Fig. 5. 6. 7). The drawings show a linear trend line. 


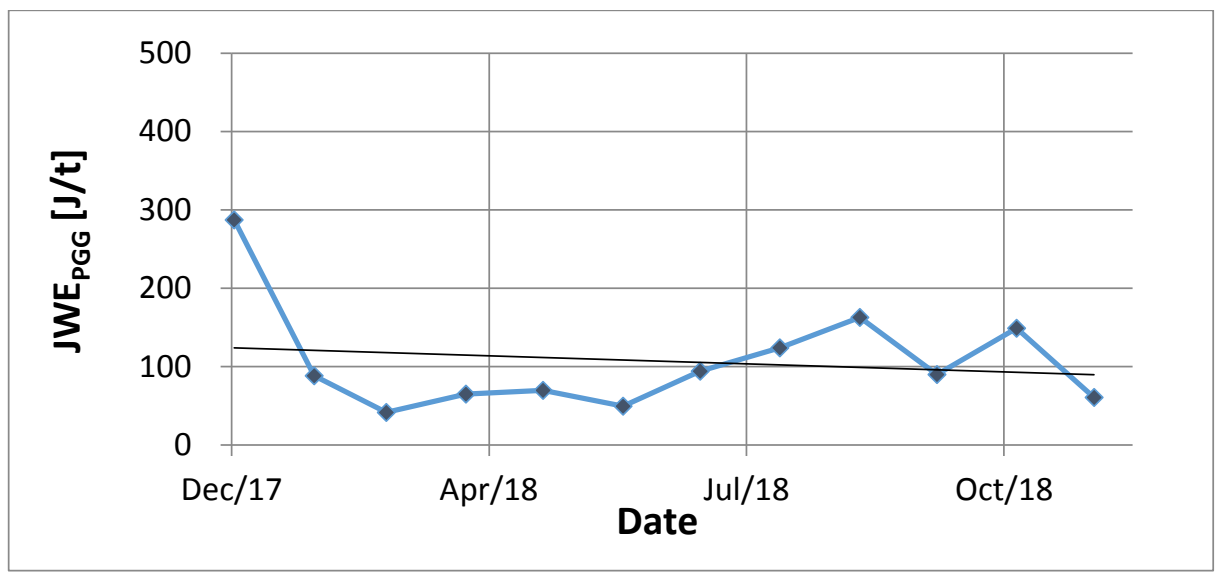

Fig. 4. Distribution of unit energy expenditures of JWE (J/t) from energy $E \geq 10^{5} \mathrm{~J}$ in the months of January - December 2018 in PGG S.A. mines

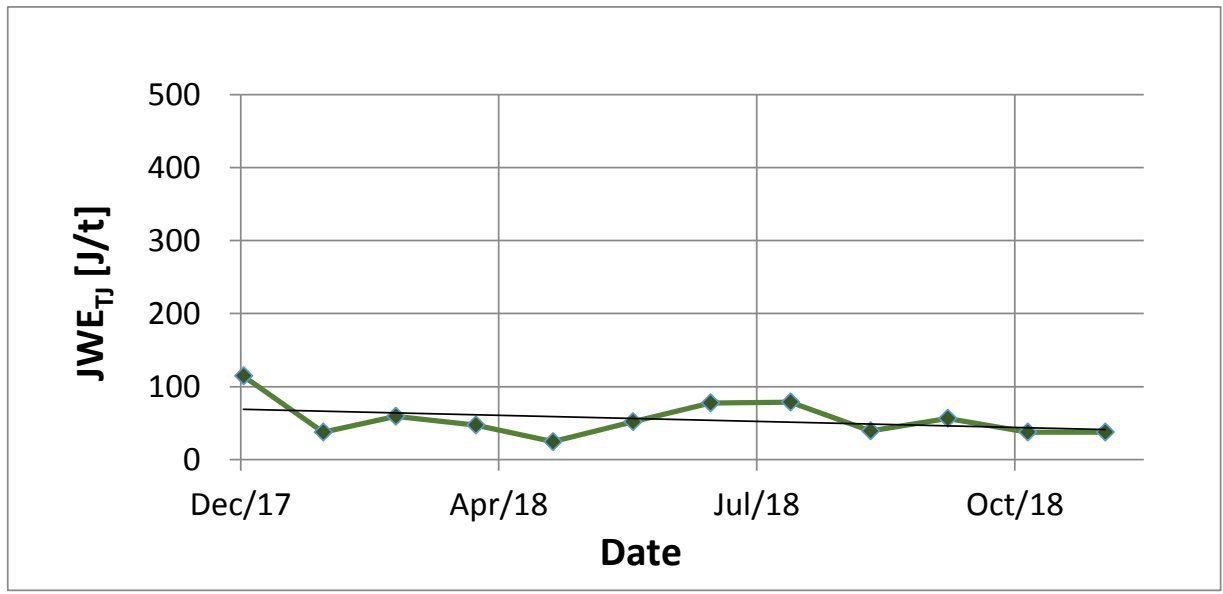

Fig. 5. Distribution of unit energy expenditures of JWE $(\mathrm{J} / \mathrm{t})$ from energy $\mathrm{E} \geq 10^{5} \mathrm{~J}$ in the months of January - December 2018 in the mines occurring within the Trogh Jejkowice range

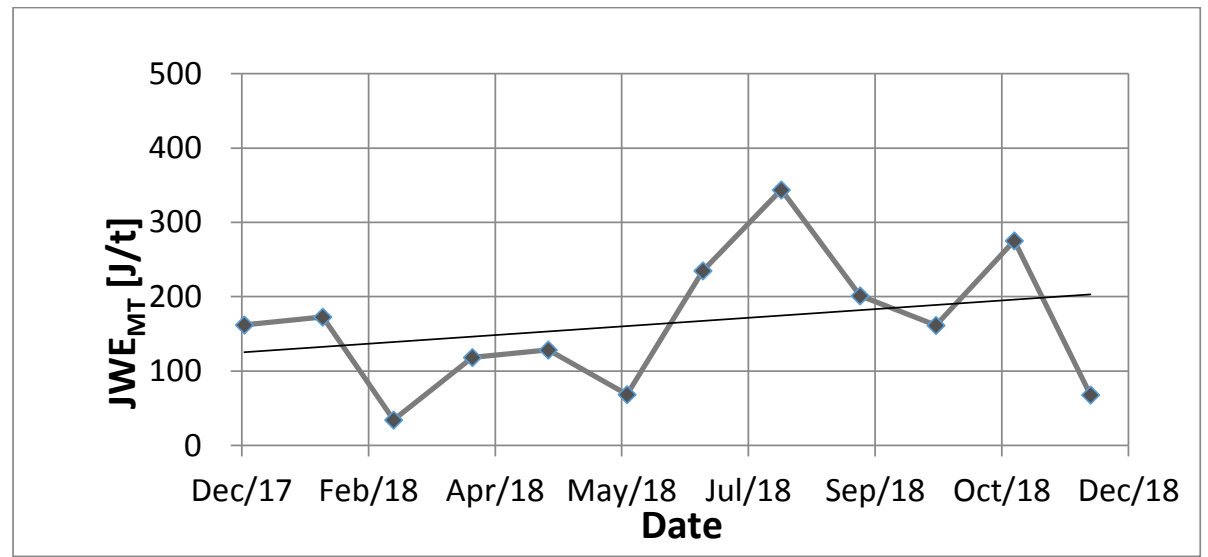

Fig. 6. Distribution of unit energy expenditures of JWE (J/t) from energy E $\geq 10^{5} \mathrm{~J}$ in the months of January - December 2018 in mines occurring within the scope of the Main Trough 


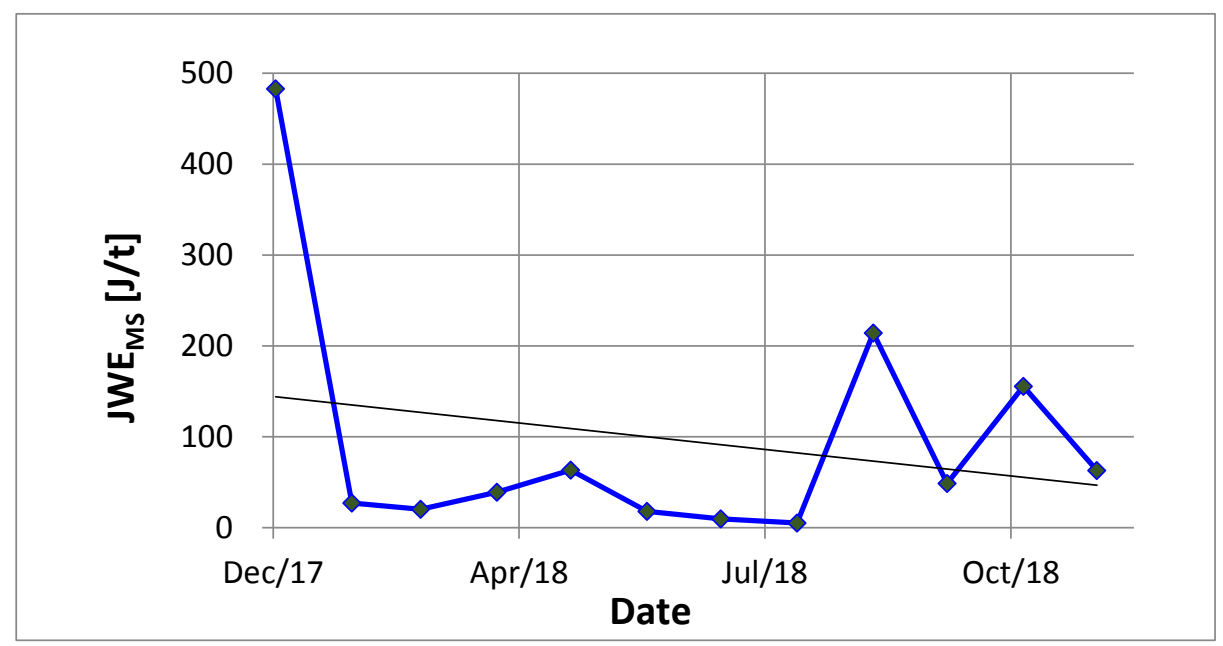

Fig. 7. Distribution of unit energy expenditures of JWE (J/t) from energy $E \geq 10^{5} \mathrm{~J}$ in the months of January - December 2019 in mines occurring within the range of the Main Saddle

\section{Summary}

The analysis of the data shows that despite of decreasing production in PGG mines in 2018 (Fig. 2) and declining of JWE (Fig. 4) the distribution of JWE in individual tectonic units is diversified. The distribution of JWE in the main trough shows an upward trend (tab. 2). The largest percentage share of the number and energy of induced vibrations can be observed in the main trough. This testifies to the seismic hazard for the mining areas of KWK Ziemowit - Piast. It creates a real threat to buildings and infrastructure on the surface due to the occurrence of high-energy tremors induced by mining activities. The tremors in the main trough can reach energy of $10^{9}$ Joules, which is compared to small earthquakes. In 2010 such a tremor occurred in KWK Piast causing a lot of damages on the surface.

The analysis clearly shows that the seismic hazard in PGG mines differed in tectonic units. The level of seismic activity in the analyzed period fluctuated and depended on the intensity of exploitation and mining and geological conditions in a given region. Coal mining output in Poland decreases year by year, but the energy of tremors, especially those of high energetic levels $>10^{6} \mathrm{~J}$ increases. The most important and strongest ones have been detected mainly in the region of two stuctural units: Main Suddle and Main Trough. Although their seismic activity is similar. The Main Trough area is much less populated. The most populated region of the Upper Silesia with some of its greatest cities is directly located above the area of exploitation in the Main Suddle. In the past Main Suddle had the most dangeorus tremors which resulted in damages to buildings. In the future the risk of significant structural damage especially in rural areas will be even higher. The problem will mostly affect old buildings kept in bad technical condition.

\section{References}

1. W. Konopko. R. Patyńska. Warunki występowania tapnięć w kopalniach węgla kamiennego. [Conditions of occurrence of rock bursts in coal mines]. Przegląd Górniczy. Vol. 1. p. 12-17 (2008)

2. R. Patyńska. Uwarunkowania górniczo-geologiczne eksploatacji pokładów zagrożonych tapaniami $w$ latach 1987-2007. [Mining and geological conditions of exploitation of 
seams with rock burst hazard between 1987 and 2007]. Wydawnictwo IGSMiE PAN. Gospodarka Surowcami Mineralnymi. Kwartalnik. Vol. 24- Book 2/3. Kraków. p. 227243 (2008)

3. R. Patyńska. Tapania a tektonika Górnośląskiego Zagłębia Węglowego. [Rock bursts and tectonics of the Upper Silesian Coal Basin]. XXVII Zimowa Szkoła Mechaniki Górotworu. Wyd. Katedry Geomechaniki Budownictwa i Geotechniki Tom II. Kraków. p. 741-753 (2004)

4. R. Patyńska i in.. Zagrożenie Tapaniami. [w] [Rockburst hazard]. [in] Raport rocznyo stanie zagrożeń naturalnych i technicznych $w$ górnictwie węgla kamiennego. Central Mining Institute. Katowice (2002-2018)

5. Z. Burtan, J. Cieślik and D. Chlebowski. Seismicity induced by hard coal mining in the vicinity of faults, E3S Web of Conferences 66, 01008 (2018) https://doi.org/10.1051/e3sconf/20186601008

6. R. Patyńska. A. Mirek. Z. Burtan. E. Pilecka: Rockburst parameters causing mining disasters in Mines of Upper Silesian Coal Basin. E3S Web of Conferences; Tom 24. 2017; AG 2017 - III Międzynarodowa Konferencja na temat Geofizyki Stosowanej; No. article 01010

7. Z. Szreder, Z.Pilecki, J. Kłosiński, 2008: Effectiveness of the recognition of the exploitation edge influence with the help of profiling attenuation and velocity of seismic wave. Gospodarka Surowcami Mineralnymi, vol. 24, Issue 2, 215-226.

8. A. Krawczyk, R. Grzybek : An evaluation of processing InSAR Sentinel-1A/B data for correlation of mining subsidence with mining induced tremors in the Upper Silesian Coal Basin (Poland). E3S Web of Conferences 26, 00003 (2018), https://doi.org/10.1051/e3sconf/20182600003

9. E. Pilecka, Z. Pilecki, 2006: Analysis of relation between induced seismic activity and satelite data. $19^{\text {th }}$ Symposium on Application of Geophysics to Engineering and Environmental Problems SAGEEP, EEGS, 2-6 April 2006, Seattle, USA, 346-355.

10. E. Pilecka, Z. Pilecki, 2007: The changes in lineaments locations in the zones of seismicity induced by mining. Proc. $13^{\text {th }}$ European Meeting of Environmental and Engineering Geophysics “Near Surface 2007”, EAGE, 3-5 Sept. 2007, Istanbul, Turkey.

11. R. Patyńska. K. Stec. Regional Rockburst Indicator for structural units of Upper Silesian Coal Basin. Oficyna Wydawnicza Politechniki Wrocławskiej. Studia Geotechnica et Mechanica. Vol. 39 (2017). No. 2. Wrocław 2017. p. 1-14 (2017) 